\section{Croatian natural gas balancing market analysis}

Rudarsko-geološko-naftni zbornik

(The Mining-Geology-Petroleum Engineering Bulletin) UDC: 620.9

DOI: 10.17794/rgn.2020.4.5

Review scientific paper

\author{
Dominik Kevo'; Ivan Smajla², Daria Karasalihović Sedlar²; Filip Božić3 \\ ${ }^{1}$ INA-Industrija nafte, d.d., Av. V. Holjevca 10, 10000 Zagreb \\ ${ }^{2}$ University of Zagreb, Faculty of Mining, Geology and Petroleum Engineering, Pierottijeva 6, 10000 Zagreb \\ ${ }^{3}$ Bernarda Vukasa 7, 10000 Zagreb
}

\begin{abstract}
The Network Code on Gas Balancing of Transmission Networks stimulates the development of the wholesale gas market by encouraging balance responsible parties to use standardized balancing mechanisms. To balance their portfolios, balance responsible parties can use renominations of quantities at entry and exit points, trade on a virtual trading point or trade on a trading platform. In the event of a system imbalance, Plinacro, as the operator of the gas transmission system in the Republic of Croatia, activates the balancing energy to return the system within acceptable limits. In accordance with the Rules on the Organization of the Gas Market, the Croatian Energy Market Operator performs a monthly calculation of the daily imbalance charge, trades conducted on the trading platform for balancing activities, a neutrality charge and a charge for deviation from the nominated quantities which have been analysed in this paper based on the case study of a chosen balancing group. The analyses conducted in the paper have shown that the balance responsible party may be entitled to compensation or be liable to pay compensation based on the monthly calculation of the Croatian Energy Market Operator, HROTE, depending on the value of each charge. Plinacro as the forecasting party is preparing a new model for the allocation of gas quantities that will affect the operations of gas suppliers, DSOs and especially BRPs. Based on this analysis, it could be concluded that more accurate estimated consumption for a balancing group leads to cost optimization and a more transparent gas market.
\end{abstract}

\title{
Keywords:
}

positive balancing energy; negative balancing energy; balancing group; trading platform; virtual trading point.

\section{Introduction}

Natural gas has been considered an efficient and clean fuel that will have a key role in the future of European energy. The natural gas market is becoming fully internationalized since natural gas is transported by pipelines and as liquefied natural gas (hereinafter: LNG). The natural gas market is dependent on transmission network development. With the development of liquefaction technology and the construction of LNG terminals, the natural gas market expanded. Besides common factors influencing the market, market speculation is also one of the main characteristics of the natural gas market (Nosić et al., 2017). Speculations at the gas market include a combination of transport and storage, depending on prices and seasonal price spreads at natural gas hubs. Since natural gas consumption has been increasing historically and the European domestic production has been decreasing at the same time, new transport routes have emerged along with new suppliers. The security of sup-

Corresponding author: Ivan Smajla

ivan.smajla@rgn.hr ply became the main paradigm of the gas market through the last decade and regulation of the gas market led to the development of an extra complex European gas market with the intention of creating a European Integrated Gas Market by integrating national markets into a single market. The previous gas market analysis and researches confirm a very strong integration among most of the European gas markets (Chiappini et al., 2019).

According to the British Petroleum (BP) Statistical Review of World Energy 2018, international natural gas consumption rose by 82.8 million tonnes of oil equivalent (Mtoe) in 2017, which is the fastest growth since 2010 (URL1). In such circumstances, natural gas is drawing increasing attention because it is cleaner burning than coal and oil (Wu et al., 2020). The electric power sector is expected to be the main driver of the natural gas consumption increase in the future which will result in a tight coupling of both energy systems (Ordoudis et al., 2019). The gas system in Europe is facing increasing unpredictability due to interactions with the electricity generation system. Gas fired power plants make up an important back-up technology to deal with intermittency induced by renewable resources into 
the energy grid. Consequently, the flexibility needs with respect to unpredictable power generation are transferred to the gas market (Keyaerts et al., 2014) and need to be solved by market-based balancing measures taken by a transmission system operator (hereinafter: TSO). Therefore, imbalances in the gas market will become even more important.

\section{Regulatory framework}

By joining the European Union, European energy regulation has become binding upon the Republic of Croatia. From the gas market standpoint, the most important legislative adaptation was the implementation of Commission Regulation No. 312/2014 establishing a Network Code on Gas Balancing of Transmission Networks (hereinafter: Balancing Network Code). According to the Gas Market Act (URL14), a gas transmission system operator is required to balance the transmission system in accordance with:

1. the Balancing Network Code;

2. the Rules on the organization of the gas market;

3. the Network Code of the transmission system.

The Balancing Network Code was adopted with the aim of developing a wholesale gas market through a balancing regime of the gas transmission system. Balance responsible parties (hereinafter: BRP) have the primary responsibility for gas balancing. They are required to maintain the balance of gas input and output for the members of their balancing group on a daily basis. The balancing group is an association of participants in the gas market, organized on a commercial basis, primarily for the purpose of balancing and optimizing balancing costs, organized and managed by the BRP. In order to maintain the balance of the balancing group, renomination of the input and output capacities, trading on a virtual trading point with other BRPs and trading on a trading platform can be used (URL11).

If BRPs fail to balance their portfolios or their activities are insufficient, the system may slip outside the tolerated limits. Deviations of the balancing groups in the same direction put the transmission system in imbalance, which threatens its operability (Kevo, 2020). Linepack flexibility is an important balancing tool with an economic value and cost. This cost will be demonstrated to relate to the amount of capacity that has to be committed to flexibility (Keyaerts et al., 2011). If the operability of the operator is threatened, TSO must activate the balancing energy by trading on a trading platform operated by HROTE, a Croatian Energy Market Operator. The BRP can thus deliver gas to the transmission system for positive balancing energy or use gas from the transmission system as a negative balancing energy. The calculation of balancing costs for an individual balancing group on a monthly basis is performed by HROTE, in accordance with the Rules on the organization of the gas market.

\section{Croatian gas system balancing methodology}

The Rules on the organization of the gas market (URL5) regulate the procedures, principles and standards of organization and operation of the gas market according to the balance group model. The organization of $\mathrm{BRP}$, their responsibility and BRP register are prescribed along with contractual relations of the gas market operator with TSO, BRP and the balancing service provider. Transactions on the virtual trading point, as well as trading on the trading platform are described by these Rules along with balancing fees.

\subsection{Trading platform and virtual trading point}

On April 1 1t, 2017, HROTE put a trading platform into operation where BRPs and the TSO trade short-term standardized products. The Trading Platform (hereinafter: TP) is an electronic platform operated by a gas market operator that enables the transparent, non-discriminatory and anonymous trading of products (URL5). BRPs and TSO have the right to trade on the TP. Products can be offered within a gas day or for the next gas day, i.e. a day in advance.

On January $1^{\text {st }}, 2014$, a virtual trading point (hereinafter: VTP) was introduced on the gas market in the Republic of Croatia (URL12). The VTP was previously part of the SUKAP system and is now a part of the trading platform. The VTP is the place of gas trade after its entry into the transmission system and before its exit from the transmission system, including the gas storage system. The BRPs have the right to report transactions on the VTP. They negotiate transactions and regulate the mutual rights and obligations arising from transactions on the VTP, without the intervention of the transmission system operator or the gas market operator (URL6). To differentiate the two, the virtual trading point is a part of the trading platform via which two balance responsible parties can perform bilateral trades with mutually agreed terms. To successfully perform the trade, both parties must enter the same contractual terms. On the other hand, the trading platform gives the balance responsible parties an opportunity to anonymously offer products or buy listed products. Only after the completed sale/purchase, the opposite trade party is revealed.

\subsection{Transmission system balancing}

In order to ensure the necessary conditions for safe, reliable and quality gas transmission to all users of the transmission system, it is necessary to maintain the transmission system in normal operating conditions and within operational limits. Therefore, the TSO undertakes balancing actions when the imbalance exceeds the allowed margin (+/- 2.500 MWh from the reference point), i.e. to reach an acceptable position of operational accumulation at the end of the day (URL10). The amount of 


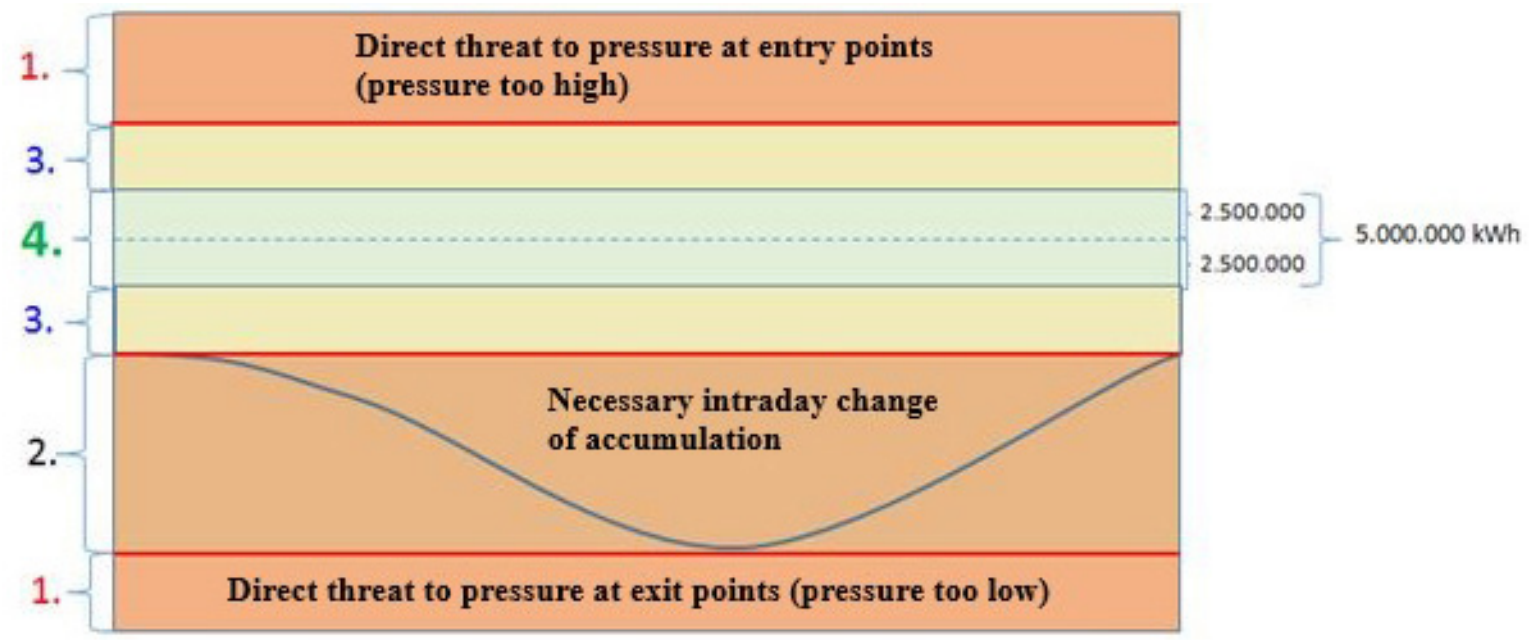

Figure 1: Possible transmission system positions depending on operational accumulation (URLio)

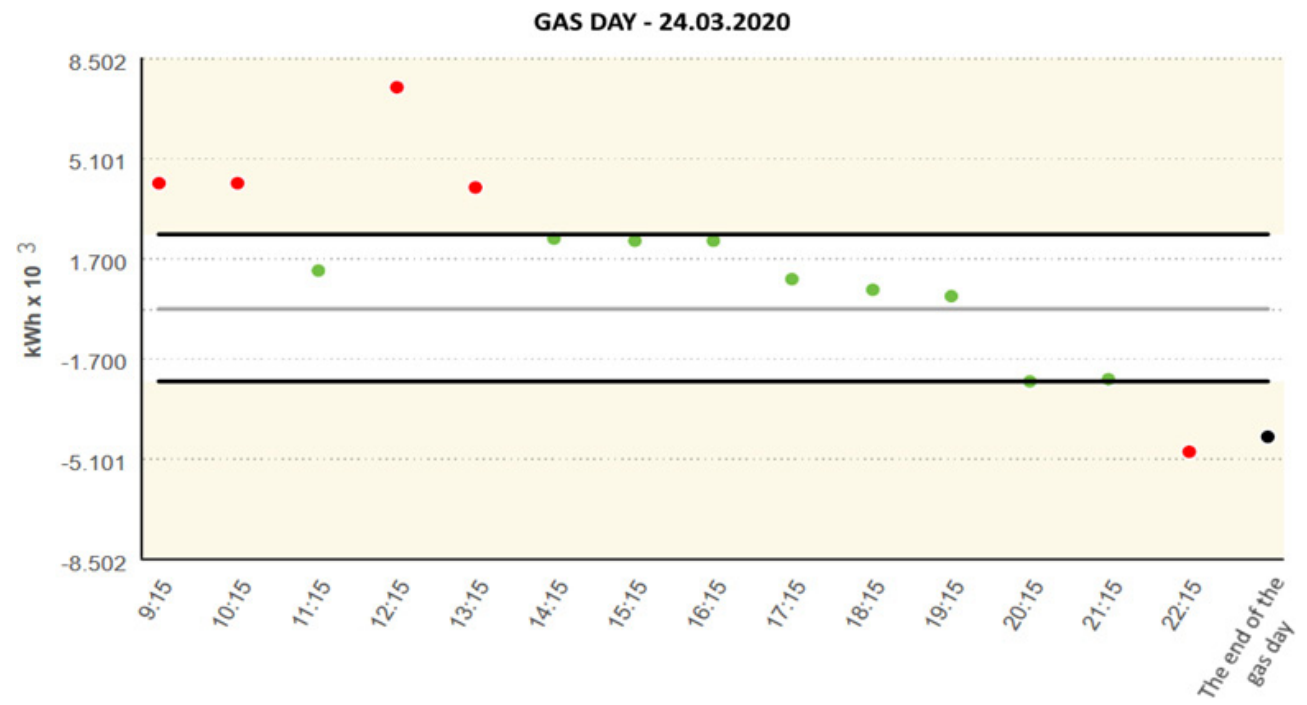

Figure 2: Estimated total deviation at the end of gas day (URL13)

compressed gas stored in the transmission system, excluding gas for technological capacities used by TSO, is called operational accumulation (URL14). Figure 1 shows the 4 positions of the transmission system depending on the operational accumulation quantity (URL10):

1. the lower and upper physical border of the accumulation, exceeding of which causes a direct threat to the pressures at the entry or exit points of the transmission system;

2. necessary change of accumulation during the day due to a difference in the dynamics of input and output, which allows the daily balancing regime;

3. accumulation required for a physical response to an unforeseen outage of a large input/output;

4. the area within which the transmission system operator does not take balancing actions, which is in total a range of 5.000 MWh.

\subsection{Estimated total deviation}

The TSO analyses and predicts the movement of the operational accumulation in the transmission system on a daily basis, based on data on the nominated quantities at the entry and exit points of the system and data on the estimated gas consumption. The total gas consumption on gas day D is forecasted by the TSO, taking into account the latest accepted nominations for end customers connected to the transmission system, ambient temperature forecast and historical data on gas delivery to the distribution systems. This data is included in the estimate of the total deviation, i.e. the deviation of all balancing groups for the end of gas day D, as shown in Figure 2. Estimated total deviation is determined based on the remaining deviation for gas day D-1 and the estimated deviation for gas day D (URL9).

The TSO undertakes balancing actions when the amount of the estimated total deviation at the end of the 
Table 1: Schedule for data publishing and balancing actions (URL1o)

\begin{tabular}{|c|c|c|c|c|}
\hline $\begin{array}{l}\text { Publishing estimated total daily } \\
\text { deviation }\end{array}$ & \multicolumn{4}{|c|}{ Data updates every hour between 9:30 and 22:30 on Plinacro's website } \\
\hline $\begin{array}{l}\text { Publishing overall data for transmission } \\
\text { system exit points towards distribution } \\
\text { systems }\end{array}$ & \multicolumn{4}{|c|}{ Data updates every hour on Plinacro's website } \\
\hline $\begin{array}{l}\text { Intraday report for each balancing group } \\
\text { (available on SUKAP) }\end{array}$ & \multicolumn{2}{|c|}{$\begin{array}{l}\text { until 12:00 } \\
\text { (hourly data for the period 6:00-10:00) }\end{array}$} & \multicolumn{2}{|c|}{$\begin{array}{l}\text { until 20:00 } \\
\text { (hourly data for the period 6:00 - 18:00) }\end{array}$} \\
\hline $\begin{array}{l}\text { Intraday report for transmission system } \\
\text { exit points (available on SUKAP) }\end{array}$ & \multicolumn{2}{|c|}{$\begin{array}{l}\text { until 12:00 } \\
\text { (hourly data for the period 6:00 - 10:00) }\end{array}$} & \multicolumn{2}{|c|}{$\begin{array}{l}\text { until 20:00 } \\
\text { (hourly data for the period 6:00-18:00) }\end{array}$} \\
\hline $\begin{array}{l}\text { Balancing activities performed by the } \\
\text { TSO }\end{array}$ & 9:30-10:00 & $13: 30-14: 00$ & $17: 30-18: 00$ & 20:30-21:00 \\
\hline
\end{tabular}

gas day is outside the span of tolerance (URL9). Plinacro performs balancing activities using short-term standardized products or a balancing service through a trading platform. Plinacro publishes data for BRPs and undertakes balancing actions during gas day $\mathrm{D}$ according to the terms specified in Table 1.

\subsection{Allocating the gas consumption}

The TSO allocates daily measured quantities of gas at the entry and exit points to users of the transmission system. The allocated quota is the amount of gas attributed by the TSO to end users expressed in $\mathrm{kWh}$ for the purpose of determining the daily imbalance (URL2). The allocation of measured quantities at the exit point of the transmission system is performed in two phases (Jovanovac et al., 2019):

- initial allocation at the end of the gas day (in proportion to user nominations);

- monthly allocation performed by the distribution system operator (hereinafter: DSO) at the entrance to its system.

Initial or daily allocations are performed by the TSO for gas day $\mathrm{D}$ based on the measured gas quantities at each entry and exit point of the transmission system, in proportion to the share of the last accepted nomination in the sum of all accepted nominations for each entry and exit point (URL9).

Monthly allocations are performed by the DSO based on the metered or calculated data on exits (metering points) from the distribution system. A metering point is a place on the transmission system with a built-in gas meter, measuring, regulation and safety equipment, where the volume is measured to calculate the delivered gas quantity (URL9). The Network code of the distribution system (URL4) prescribes that metering points of tariff models (hereinafter: TM) TM6 to TM12 must be equipped for remote reading. That means that data for TM6 to TM12 is measured by the DSO while the data for TM1 to TM5 is calculated based on previous consumption and standard consumption profiles. TMs are groups of metering points with a certain range of annual gas consumption.

\subsection{Disadvantages of the current system}

Due to the inconsistent methodology, the differences between daily estimates and monthly reports are often large. Plinacro as a forecasting party delivers to BRPs forecasts of gas consumption for end users which are members of their balancing group, for tariff models TM1 to TM5. Plinacro cannot guarantee the accuracy of this information and states that it is of an informative nature (URL9). Based on this data, BRP should predict the deviation of its balancing group and react adequately, i.e. balance its portfolio. Due to different daily and monthly allocation methods, BRPs do not have adequate data and are often not ready to balance their balancing group (Kevo, 2020). Also, the current rules do not ensure equality when allocating gas consumption for metering points without daily measurement as the remaining difference after allocating suppliers and BRPs is attributed to the supplier on the wholesale market (Jovanovac et al., 2019). Since the current practice is not in line with the Balancing Network Code, a new prediction methodology and advanced allocation model at the entries to distribution system is planned to be introduced in October 2020.

Additionally, the calculation of energy at the lower heating value stands out as a potential problem. Namely, the energy of the gas traded on the European market is calculated on the higher heating value, and the same applies to the booking of capacities at pipeline interconnections. After the transfer of gas to the Croatian gas system, the booking of capacity is carried out on the lower heating value, as well as the billing for the delivered energy to end users (URL11). Finally, in reporting to ACER (the Agency for the Cooperation of Energy Regulators) and CEER (the Council of European Energy Regulators), as well as for statistical reports to EUROSTAT, the Croatian Energy Regulatory Agency (hereinafter: HERA) recalculates the data to the higher heating value, dividing the amount of energy by a conversion factor of 0.901 . The introduction of energy calculation of the delivered gas on the higher heating value would eliminate the possibility of errors in the supply chain of gas, capacity booking and statistical reporting to the competent European authorities. 


\section{Monthly charges calculated by gas market operator}

Pursuant to the Rules on the Organization of the Gas Market (URL5), HROTE submits each BRP a calculation for its balancing group and related invoices for the previous month by $16: 00$ on the third working day after the publication of the final report for the previous month. If BRP is due a fee from the gas market operator, an invoice must be issued by the twentieth day of the month for the previous month. The market operator shall calculate for each month:

1. a daily imbalance charge;

2. trading on the trading platform for undertaken balancing actions;

3. neutrality charge for balancing;

4. deviation from the nomination.

\subsection{Daily imbalance charge}

The daily imbalance of the balancing group is the difference between delivered and taken quantities of gas from the transmission system in gas day D taking into account accepted transactions on the VTP, concluded trades on the TP and activated balancing energy for balancing service (URL9). If the balancing group delivers more gas to the transmission system in one gas day than it takes from the transmission system, it has achieved a positive daily imbalance. Vice versa, if the balancing group takes more than it delivers, a negative daily imbalance is determined for the balancing group. The daily imbalance charge is determined by multiplying the amount of the daily imbalance of the balancing group for a gas day $\mathrm{D}$ by the applicable price.

The applicable price can be (URL5):

a) the marginal sale price - the price used to calculate a positive daily imbalance charge (when delivered quantities to transmission system are greater than the quantities taken from the system); or

b) the marginal purchase price - the price applied for the calculation of a negative daily imbalance charge (when the quantities taken from transmission system are higher than the delivered quantities to the system).

These prices are calculated for each gas day as follows (URL5):

1. The marginal sale price is the lower one of the following two:

a) the lowest price of all sales in which the TSO participates during the gas day; or

b) the weighted average gas price for that gas day reduced by $10 \%$;

2. The marginal purchase price is the higher one of the following two:

a) the highest price of all purchases in which the TSO participates during the gas day; or

b) the weighted average gas price for that gas day increased by $10 \%$.

Table 2 shows the beginning of monthly calculation for daily imbalance charges for balancing group " $\mathrm{X}$ ". The sum of delivered quantities at the transmission system entry points and the purchases at the VTP and TP is reduced by a sum of the taken quantities at the exit points from the transmission system and sales at the VTP and TP (Kevo, 2020). If the daily imbalance is positive, it is multiplied by the marginal sale price to calculate a positive daily imbalance charge. Otherwise, the negative daily imbalance is multiplied by the marginal purchase price and a negative imbalance charge is calculated for that gas day (URL5). Within a month, the charges for positive daily imbalances and negative daily imbalances are summarized, as is shown in Table 3. If the sum of all positive daily imbalance charges is higher than the sum

Table 2: Comparing entries and exits for daily imbalance charge for balancing group " $\mathrm{X}$ " (Kevo, 2020)

\begin{tabular}{|l|l|l|l|l|l|l|}
\hline Gas day & $\begin{array}{l}\text { Ts - entry } \\
{[\mathrm{MWh}]}\end{array}$ & $\begin{array}{l}\text { Ts - exit } \\
{[\mathrm{MWh}]}\end{array}$ & $\begin{array}{l}\text { VTP - purchase } \\
{[\mathrm{MWh}]}\end{array}$ & $\begin{array}{l}\text { VTP - sale } \\
{[\mathrm{MWh}]}\end{array}$ & $\begin{array}{l}\text { TP - purchase } \\
{[\mathrm{MWh}]}\end{array}$ & $\begin{array}{l}\text { TP - sale } \\
{[\mathrm{MWh}]}\end{array}$ \\
\hline 1.12 .2019 & 28922 & 18215 & 12050 & 22992 & 0 & 0 \\
\hline 2.12 .2019 & 29238 & 17841 & 12050 & 23992 & 0 & 0 \\
\hline 3.12 .2019 & 29440 & 17603 & 12050 & 25392 & 1500 & 0 \\
\hline 4.12 .2019 & 31122 & 17760 & 12050 & 25392 & 0 & 0 \\
\hline 5.12 .2019 & 30237 & 17877 & 12050 & 25392 & 0 & 0 \\
\hline 6.12 .2019 & 31210 & 18167 & 12050 & 25392 & 0 & 0 \\
\hline 7.12 .2019 & 31374 & 18257 & 12050 & 25392 & 270 & 0 \\
\hline 8.12 .2019 & 31236 & 18157 & 12050 & 25392 & 0 & 0 \\
\hline 9.12 .2019 & 31867 & 18067 & 12050 & 25392 & 0 & 0 \\
\hline 10.12 .2019 & 31821 & 18285 & 12050 & 25392 & 0 & 0 \\
\hline 11.12 .2019 & 32177 & 15995 & 12050 & 25392 & 0 & 2631 \\
\hline$\ldots$ & $\ldots$ & $\ldots$ & $\ldots$ & $\ldots$ & $\ldots$ & $\ldots$ \\
\hline 31.12 .2019 & 25568 & 14774 & 12050 & 22377 & 0 & 0 \\
\hline
\end{tabular}


Table 3: Monthly calculation of the daily imbalance charges for balancing group " $\mathrm{X}$ " (Kevo, 2020)

\begin{tabular}{|l|c|c|c|c|c|c|}
\hline \multirow{2}{*}{ Gas day } & \multicolumn{2}{|c|}{ Daily imbalance $[\mathrm{MWh}]$} & \multicolumn{2}{c|}{ Marginal price [kn/MWh] } & \multicolumn{2}{c|}{ Daily imbalance charge [kn] } \\
\cline { 2 - 7 } & Positive & Negative & Sale & Purchase & Positive & Negative \\
\hline 1.12 .2019 & 0 & -235 & 305.96 & 373.95 & 0.00 & -87851.33 \\
\hline 2.12 .2019 & 0 & -544 & 305.96 & 373.95 & 0.00 & -203593.71 \\
\hline 3.12 .2019 & 0 & -5 & 166.93 & 204.03 & 0.00 & -1063.00 \\
\hline 4.12 .2019 & 20 & 0 & 200.64 & 204.03 & 3982.10 & 0.00 \\
\hline 5.12 .2019 & 0 & -982 & 200.64 & 204.03 & 0.00 & -200352.77 \\
\hline 6.12 .2019 & 0 & -299 & 200.64 & 204.03 & 0.00 & -60970.08 \\
\hline 7.12 .2019 & 44 & 0 & 183.10 & 204.03 & 8082.40 & 0.00 \\
\hline 8.12 .2019 & 0 & -263 & 184.00 & 204.03 & 0.00 & -53607.86 \\
\hline 9.12 .2019 & 459 & 0 & 184.00 & 204.03 & 84394.36 & 0.00 \\
\hline 10.12 .2019 & 194 & 0 & 177.13 & 204.03 & 34350.64 & 0.00 \\
\hline 11.12 .2019 & 209 & 0 & 177.13 & 220.22 & 37043.91 & $\ldots .00$ \\
\hline$\ldots$ & $\ldots$ & $\ldots$ & $\ldots$ & $\ldots$ & $\ldots$ & $\ldots$ \\
\hline 31.12 .2019 & 468 & 0 & 149.94 & 183.26 & 70119.29 & 0.00 \\
\hline
\end{tabular}

920463.49

Market operator issues an invoice to BRP

$464530.19 \mathrm{kn}$ of all negative daily imbalance charges, the BRP issues an invoice to the gas market operator for the difference between these charges. Otherwise, the gas market operator issues an invoice to the BRP, as is the case in the example below (Kevo, 2020).

\subsection{Trading on the trading platform for balancing actions}

Besides the daily imbalance charge, the gas market operator also calculates the balancing actions undertaken by the BRP which traded products with the TSO on the TP to balance the transmission system. The TSO shall take balancing actions if the estimated total deviation is outside the tolerated limits. The balancing action is a trade performed by the TSO with products on the TP in the amount that will reduce the estimated total deviation within the tolerated limits.

Positive balancing energy is the amount of gas delivered to the transmission system, i.e. the product that the TSO buys on the trading platform to balance the transmission system, in case of a negative estimated total deviation (URL5). In this case, the TSO must activate the positive balancing energy, i.e. buy gas, and products with a lower unit price have an advantage on the TP (URL9). BRPs that have excess gas in their portfolio may choose to offer that gas to the TSO.

On the other hand, negative balancing energy is the amount of gas taken from the transmission system, i.e. the product that the TSO sells on the trading platform to balance the transmission system, in case of a positive estimated total deviation (URL5). In this case, the TSO must activate the negative balancing energy, i.e. sell gas. BRPs can make an offer for this gas, and products with a higher unit price have an advantage on the TP. When undertaking balancing operations, the transmission system operator shall consider only product offers that have been published before the start of the balancing action period (URL9).

Table 4 shows the trading of a BRP on the TP for December 2018, i.e. shows the balancing actions undertaken by the BRP of balancing group "X". The TSO traded with this BRP 3 times to activate the positive balancing energy. Also, these entities traded 3 more times in that month to activate the negative balancing energy. The amount of positive balancing energy, i.e. the amount of gas delivered to the system by the BRP, is multiplied by the unit price accepted on the trading platform to calculate the fee that the market operator must pay to the BRP for the specified amount of gas. On the other hand, negative balancing energy, i.e. the amount of gas taken by the BRP from the gas transmission system, is multiplied by the unit price to calculate the fee that the BRP must pay to the market operator for the specified amount of gas. At the end of the month, all trades between the TSO and individual BRPs for activating positive balancing energy are summarized, as well as all trades for activating negative balancing energy. In this example, the sum of activated negative balancing energy is greater than the sum of activated positive balancing energy. Therefore, the gas market operator issues an invoice to the BRP for the difference of these fees (Kevo, 2020).

\subsection{Neutrality charge for balancing}

The gas market operator calculates the cash flow for the previous month based on the daily imbalance charge and undertaken balancing actions. For the previous 
Table 4: Trades on the TP performed by a BRP for balancing group " $X$ " (Kevo, 2020)

\begin{tabular}{|c|c|c|c|c|c|c|}
\hline \multirow[b]{2}{*}{ Gas day } & \multicolumn{3}{|c|}{ Positive balancing energy } & \multicolumn{3}{|c|}{ Negative balancing energy } \\
\hline & $\begin{array}{l}\text { Quantity } \\
\text { [MWh] }\end{array}$ & $\begin{array}{l}\text { Unit price } \\
{[\mathrm{kn} / \mathrm{MWh}]}\end{array}$ & $\begin{array}{c}\text { Amount } \\
{[\mathrm{kn}]}\end{array}$ & $\begin{array}{l}\text { Quantity } \\
\text { [MWh] }\end{array}$ & $\begin{array}{l}\text { Unit price } \\
{[\mathrm{kn} / \mathrm{MWh}]}\end{array}$ & $\begin{array}{l}\text { Amount } \\
{[\mathrm{kn}]}\end{array}$ \\
\hline 1.12 .2019 & 0 & & & 0 & & \\
\hline 2.12.2019 & 0 & & & 0 & & \\
\hline 3.12.2019 & 1500 & 194.07 & 291105.00 & 0 & & \\
\hline 4.12.2019 & 0 & & & 0 & & \\
\hline 5.12 .2019 & 0 & & & 0 & & \\
\hline 6.12.2019 & 0 & & & 0 & & \\
\hline 7.12.2019 & 270 & 183.91 & 49655.70 & 0 & & \\
\hline 8.12.2019 & 0 & & & 0 & & \\
\hline 9.12.2019 & 0 & & & 0 & & \\
\hline 10.12.2019 & 0 & & & 0 & & \\
\hline 11.12.2019 & 0 & & & 2631 & 220.22 & 579398.82 \\
\hline$\cdots$ & $\ldots$ & $\ldots$ & $\ldots$ & $\ldots$ & $\ldots$ & $\ldots$ \\
\hline 31.12.2019 & 0 & & & 0 & & \\
\hline & 3529.00 & & 688180.79 & 4241.00 & & 979252.62 \\
\hline
\end{tabular}

Market operator issues an invoice to BRP

291071.83 kn

Table 5. Comparing the total daily deviation and the daily imbalance of the balancing group " $\mathrm{X}$ " (Kevo, 2020)

\begin{tabular}{|c|c|c|c|c|}
\hline \multirow{2}{*}{ Gas day } & \multirow{2}{*}{$\begin{array}{c}\text { Total daily deviation, } \\
\text { qBS [MWh] }\end{array}$} & \multirow{2}{*}{$\begin{array}{l}\text { Daily imbalance for balancing } \\
\text { group "X", qBS [MWh] }\end{array}$} & \multicolumn{2}{|c|}{ Absolute daily imbalance [MWh] } \\
\hline & & & Same as qBS (causer) & Opposite to qBS (helper) \\
\hline 1.12.2019 & 1040 & -235 & 0 & 235 \\
\hline 2.12.2019 & 1827 & -544 & 0 & 544 \\
\hline 3.12.2019 & 2329 & -5 & 0 & 5 \\
\hline 4.12.2019 & 2531 & 20 & 20 & 0 \\
\hline 5.12.2019 & -937 & -982 & 982 & 0 \\
\hline 6.12.2019 & 1481 & -299 & 0 & 299 \\
\hline 7.12.2019 & 4131 & 44 & 44 & 0 \\
\hline 8.12.2019 & 1347 & -263 & 0 & 263 \\
\hline 9.12.2019 & 4379 & 459 & 459 & 0 \\
\hline 10.12.2019 & 1981 & 194 & 194 & 0 \\
\hline 11.12.2019 & 1811 & 209 & 209 & 0 \\
\hline$\ldots$ & $\ldots$ & $\ldots$ & $\ldots$ & $\ldots$ \\
\hline 31.12.2019 & 3042 & 468 & 468 & 0 \\
\hline
\end{tabular}

month, a profit or loss on the gas market operator's account is determined. Neutrality is a principle according to which the gas market operator must be neither at a profit nor at a loss after the calculations related to the balancing of the transmission system have been performed (URL5). In other words, if a gas market operator after calculating the neutrality charge makes a profit, those BRPs whose daily imbalances were opposite to the total daily deviation of all BRPs receive a fee. Since they helped the system stay in balance that day, they are the so-called helpers (Kevo, 2020).
Table 5 shows the beginning of the neutrality charge calculation. The first step is to determine if the daily imbalance of the balancing group " $X$ " and the total deviation for that gas day are positive or negative. If both are the same, the balancing group " $X$ " caused an imbalance for that day, i.e. it was a causer. In contrast, when one is positive and other is negative, it is considered that the balancing group " $\mathrm{X}$ " was a helper (Kevo, 2020).

The total daily deviation and balance on the account of the gas market operator are published by HROTE on its website before calculating the neutrality charge 
Table 6. Monthly calculation of neutrality charge for balancing group "X" (Kevo, 2020)

\begin{tabular}{|l|r|}
\hline $\begin{array}{l}\text { Sum of daily imbalances of all balancing groups in the same sign } \\
\text { as total daily deviation [MWh] }\end{array}$ & $\mathbf{9 2 6 5 2}$ \\
\hline $\begin{array}{l}\text { Sum of daily imbalances of all balancing groups in the opposite sign } \\
\text { from total daily deviation [MWh] }\end{array}$ & 34583 \\
\hline $\begin{array}{l}\text { Sum of daily imbalances of balancing group "X" in the same sign } \\
\text { as total daily deviation [MWh] }\end{array}$ & $\mathbf{7 3 6 6}$ \\
\hline $\begin{array}{l}\text { Sum of daily imbalances of balancing group "X" in the opposite sign } \\
\text { from total daily deviation [MWh] }\end{array}$ & $\mathbf{7 . 9 5 \%}$ \\
\hline Balancing group share in neutrality charge in case of loss & $11.94 \%$ \\
\hline Balancing group share in neutrality charge in case of profit & 5811396.54 \\
\hline $\begin{array}{l}\text { Balance of the account of the gas market operator due to undertaken } \\
\text { balancing actions [kn] }\end{array}$ & $\mathbf{- 7 5 4 8 1 4 5 . 3 6}$ \\
\hline $\begin{array}{l}\text { Balance of the account of the gas market operator due to daily } \\
\text { imbalance charge [kn] }\end{array}$ & $\mathbf{- 1 7 3 6 7 4 8 . 8 2}$ \\
\hline Total balance of the account of the gas market operator [kn] & \\
\hline
\end{tabular}

Market operator issues an invoice to BRP

$138071.53 \mathrm{kn}$

(URL8). The share of an individual balancing group both for helpers and causers is calculated and multiplied by the loss or profit on the account of the gas market operator in order to obtain the neutrality fee for an individual balancing group. Given that the gas market operator made a loss in this example, invoices were issued to all BRPs whose daily deviations are in the same sign as the total daily deviation for that gas day (see Table 6). This method of calculating the neutrality charge ensures a proportional distribution to all balancing groups that have caused an imbalance to the system in any day of the previous month (Kevo, 2020).

\subsection{Deviation from the nomination}

Unlike previous charges that are included in the neutrality charge, there is a fee that is not included in the neutrality charge but is a part of the HROTE's monthly calculations. This is a charge for deviating from the nominations and is calculated by the gas market operator

Table 7. Monthly calculation of the deviation from the nomination charge for balancing group "X" (Kevo, 2020)

\begin{tabular}{|l|c|c|c|c|c|}
\hline Gas day & $\begin{array}{c}\text { Nominated, Nbs } \\
{[\mathrm{MWh}]}\end{array}$ & $\begin{array}{c}\text { Allocated, Vbs } \\
{[\mathrm{MWh}]}\end{array}$ & $\begin{array}{c}\text { Deviation from } \\
\text { nomination, } \Delta \mathrm{Nbs} \\
{[\mathrm{MWh}]}\end{array}$ & $\begin{array}{c}\text { Unit price } \\
{[\mathrm{kn} / \mathrm{MWh}]}\end{array}$ & $\begin{array}{c}\text { Amount } \\
{[\mathrm{kn}]}\end{array}$ \\
\hline $\mathbf{1 . 1 2 . 2 0 1 9}$ & 39120 & 41316 & 2196 & 6.1184 & 13437.55 \\
\hline $\mathbf{2 . 1 2 . 2 0 1 9}$ & 39126 & 41495 & 2369 & 6.1184 & 14495.15 \\
\hline $\mathbf{3 . 1 2 . 2 0 1 9}$ & 39126 & 41618 & 2491 & 6.1184 & 15242.92 \\
\hline $\mathbf{4 . 1 2 . 2 0 1 9}$ & 39774 & 41457 & 1683 & 6.1184 & 10296.81 \\
\hline $\mathbf{5 . 1 2 . 2 0 1 9}$ & 39478 & 41222 & 1744 & 6.1184 & 18547.37 \\
\hline $\mathbf{6 . 1 2 . 2 0 1 9}$ & 39653 & 42685 & 3031 & 6.1184 & 13658.55 \\
\hline $\mathbf{7 . 1 2 . 2 0 1 9}$ & 39763 & 41995 & 2232 & 6.1184 & 12300.99 \\
\hline $\mathbf{8 . 1 2 . 2 0 1 9}$ & 40291 & 42302 & 2010 & 6.1184 & 1058.97 \\
\hline $\mathbf{9 . 1 2 . 2 0 1 9}$ & 40290 & 42098 & 1807 & 6.1184 & 10887.86 \\
\hline $\mathbf{1 0 . 1 2 . 2 0 1 9}$ & 40123 & 41903 & 1780 & 6.1184 & $\ldots$ \\
\hline $\mathbf{1 1 . 1 2 . 2 0 1 9}$ & 39822 & 42475 & 2653 & 6.1184 & $\ldots$ \\
\hline $\mathbf{\ldots}$ & $\ldots$ & $\ldots$ & $\ldots$ & 6.1184 & 10257.88 \\
\hline $\mathbf{3 1 . 1 2 . 2 0 1 9}$ & 35989 & 37666 & 1677 & & $\ldots$ \\
\hline
\end{tabular}


Table 8. Monthly sum of system imbalances in Croatia in comparison with monthly sum of activated negative and positive balancing energy (URL7)

\begin{tabular}{|c|c|c|c|c|c|}
\hline Month & Year & $\begin{array}{l}\text { Positive deviations } \\
\text { [MWh] }\end{array}$ & $\begin{array}{c}\text { Negative balancing } \\
\text { energy [MWh] }\end{array}$ & $\begin{array}{c}\text { Negative deviations } \\
{[\mathrm{MWh}]}\end{array}$ & $\begin{array}{c}\text { Positive balancing energy } \\
\text { [MWh] }\end{array}$ \\
\hline 10 & 2017 & -19728 & 14364 & 28686 & -19931 \\
\hline 11 & 2017 & -6875 & 2316 & 42481 & -40426 \\
\hline 12 & 2017 & -7117 & 5061 & 61191 & -45737 \\
\hline 1 & 2018 & -2005 & 2036 & 70610 & -70338 \\
\hline 2 & 2018 & -13225 & 11101 & 33097 & -39639 \\
\hline 3 & 2018 & -14772 & 11386 & 61080 & -56861 \\
\hline 4 & 2018 & -19305 & 8115 & 26220 & -12576 \\
\hline 5 & 2018 & -10065 & 6049 & 9214 & -6420 \\
\hline 6 & 2018 & -6486 & 1925 & 12469 & -4251 \\
\hline 7 & 2018 & -8574 & 4819 & 8029 & -2209 \\
\hline 8 & 2018 & -5826 & - & 21289 & -17248 \\
\hline 9 & 2018 & -16024 & 12660 & 20075 & -20317 \\
\hline 10 & 2018 & -6744 & 13360 & 50334 & -42495 \\
\hline 11 & 2018 & -22527 & 13542 & 17148 & -12024 \\
\hline 12 & 2018 & -5187 & 13662 & 51305 & -49494 \\
\hline 1 & 2019 & -7098 & 8765 & 44875 & -46505 \\
\hline 2 & 2019 & -15658 & 13033 & 39867 & -49661 \\
\hline 3 & 2019 & -18333 & 12283 & 44872 & -43076 \\
\hline 4 & 2019 & -31265 & 16391 & 36964 & -16436 \\
\hline 5 & 2019 & -56668 & 54290 & 9578 & -9547 \\
\hline 6 & 2019 & -12324 & 4016 & 15149 & -1990 \\
\hline 7 & 2019 & -20167 & 18850 & 3714 & - \\
\hline 8 & 2019 & -18450 & 13231 & 1584 & -1888 \\
\hline 9 & 2019 & -17502 & 11772 & 13751 & -5272 \\
\hline 10 & 2019 & -35182 & 32745 & 20549 & -16349 \\
\hline 11 & 2019 & -6402 & - & 22363 & -10748 \\
\hline 12 & 2019 & -16337 & 21009 & 25788 & -19417 \\
\hline 1 & 2020 & -23811 & 14608 & 27268 & -22482 \\
\hline 2 & 2020 & -30503 & 23988 & 15960 & -15179 \\
\hline 3 & 2020 & -17619 & 22266 & 71915 & -73538 \\
\hline 4 & 2020 & -24110 & 17134 & 18642 & -8848 \\
\hline 5 & 2020 & -23881 & 7914 & 25232 & -15959 \\
\hline 6 & 2020 & -10292 & 6454 & 24794 & -14786 \\
\hline
\end{tabular}

and submitted to the BRPs. Nomination is an announcement of the amount of natural gas for the next gas day that the users of the transmission system, i.e. members of the balancing group, intend to deliver to the transmission system and/or take from the transmission system. The transmission system user is a member of a certain balancing group for which the BRP submits a daily nomination, i.e. an announcement of the amount of gas that is intended to be delivered to or taken from the transmission system in the next gas day. The nomination must contain the planned daily amount of gas, expressed by hours of the next gas day in $\mathrm{kWh} / \mathrm{h}$. The nomination of daily quantities for an individual user of the transmission system cannot be higher than the total booked capacity at each entry or exit point for the next gas day (URL9).
If a deviation from the nomination $(\Delta \mathrm{Nbs})$ is determined for an individual balancing group at the end of the gas day, the gas market operator is obliged to issue an invoice to the BRP. The amount charged for the deviation from the nomination is obtained by multiplying $3 \%$ of the average monthly applicable gas price and the determined deviation from the nomination. The gas market operator issues an invoice to the BRP for deviation from the nomination, and the collected fees will be forwarded to the forecasting party, i.e. Plinacro (URL5). Table 7 shows the calculation of the deviation from the nomination in which the absolute value of the difference between the nominated and allocated quantities is multiplied by the unit price. In reality, the quantities allocated at the end of the month can often differ greatly from the daily estimate of the forecasting party, which can in- 


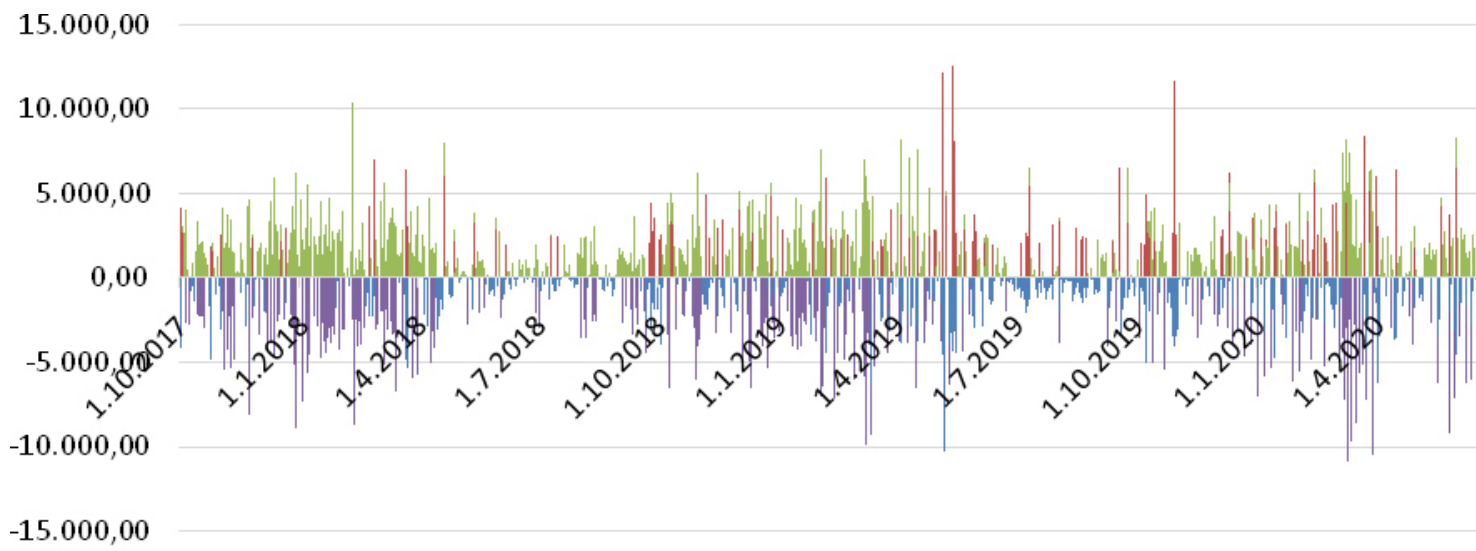

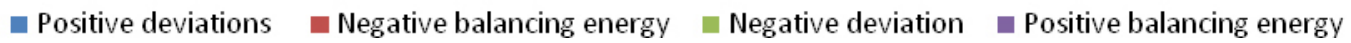

Figure 3: Activation of balancing energy and system deviations in Croatia (URL7)

crease the amount charged for BRPs that seek to reduce deviation from the nomination on a daily basis (Kevo, 2020).

Finally, based on all justified operating expenses of the Croatian Energy Market Operator, HERA issued a Decision on the fee for organizing the gas market. According to this Decision, HROTE, as the energy market operator in the Republic of Croatia, is entitled to a fee of $0.0877 \mathrm{HRK} / \mathrm{MWh}$ of gas allocated to balancing groups at the exits from the transmission system. The calculation of this fee does not include the amount of gas measured at the exit point of the transmission system of the Republic of Croatia, which is also the entry point to the gas storage system. In addition, each BRP is charged in the amount of HRK 10.000,00 per year as a fee for participation in the gas market in the Republic of Croatia (URL3).

\section{Implementation of daily balancing market in Croatia}

Joint efforts of the Croatian Energy Regulatory Agency, HERA, the Croatian Energy Market Operator, HROTE and the Croatian transmission system operator, Plinacro, resulted in the launching of the trading platform for short term standardised products for balancing actions in Croatia as of April 1 $1^{\text {st }}, 2017$. The visibility of the, already then, relative market liquidity, is seen almost instantly at the start of use of the platform and trading of the short-term products between themselves and the TSO in a similar amount from its very start of use until today.

As visible in Table 8, with monthly summary figures of activated negative balancing energy for positive system deviations and activated positive balancing energy for negative system deviations, but even more important, netted all figures together, ending in figures close to zero on monthly, quarterly or even larger scales, prove actually, after more than two years, a good assessment of the transmission system physical preconditions and abilities in comparison with system user needs and the general demand for natural gas by the professionals who developed the methodology and platform itself.

\section{Conclusion}

The prediction of gas consumption became the prerequisite of the security of gas supply that had been heavily regulated at first. Differences between real gas consumption and prediction of natural gas demand lead to imbalances in the gas market. Therefore, natural gas consumption has become more and more analysed. However, single sector market analyses will no longer be sufficient, so for further research, the authors suggest analysing physical integration across sectors, both in terms of analysing the financial basis for the individual types of technology, as well as understanding the dynamics of the individual markets. Therefore, the electricity market needs to be analysed together with natural gas, liquids and heat markets.

As natural gas markets have developed and integrated, European gas market legislation development followed. Based on research findings of conducted analyses, it could be concluded that the implementation of European natural gas legislation has had numerous positive effects on the gas system of the Republic of Croatia. The application of the Balancing Network Code has led to the integration of Croatia into the European gas market, making the transmission system more balanced and therefore effective on a daily basis, as well as paving the path for further development: the installation of smart metering for a higher share of totally installed measurement units, etc. Many EU requirements were accomplished, such as achieving a market-dictated gas price, strengthening the role of customers, facilitating access to the gas system and raising the security of the gas sup- 
ply, but also providing the Croatian natural gas market with the possibility to be in the line with other European markets with a tendency to one day become a fully liquid and organised market with a proper liquid exchange, first on the spot market (within one day and a day ahead) and later in future markets.

However, there is still room for improvement, primarily in terms of harmonizing the calculation of the delivered gas with European standards, because all EU members except the Republic of Croatia use a higher heating value as a reference. Calculating gas consumption according to the upper calorific value would lead to a simplified capacity booking, gas transmission and gas trading. Additionally, the current practice does not ensure equality for all users when calculating consumption on metering points without daily measurements. Plinacro as the forecasting party is preparing a new model for the allocation of gas quantities that will affect the operations of gas suppliers, DSOs and especially BRPs. Should they receive a more accurate estimated consumption for their balancing group, as it has been analysed in paper, they could balance the group portfolio better and optimize their costs. The last mentioned should result in a total daily balancing market position with an even more transparent market as a final effect where all potential EU traders could reconsider their entrance to Croatia.

\section{References}

\section{Papers:}

Chiappini, R., Jégourel, Y. and Raymond, P. (2019): Towards a worldwide integrated market? New evidence on the dynamics of U.S., European and Asian natural gas prices. Energy Economics, 81,545-565. https://doi.org/10.1016/j. eneco.2019.04.020

Keyaerts, N., Hallack, M., Glachant, J. M. and D'haeseleer, W. (2011): Gas market distorting effects of imbalanced gas balancing rules: Inefficient regulation of pipeline flexibility, Energy Policy, 39(2), 865-876, https://doi.org/10.1016/j. enpol.2010.11.006.

Keyaerts, N., Delarue, E., Rombauts, Y. and D'haeseleer, W. (2014): Impact of unpredictable renewables on gas-balancing design in Europe, Applied Energy, 119, 266-277, https://doi.org/10.1016/j.apenergy.2014.01.011.

Nosić, A., Karasalihović Sedlar, D., Jukić, L. (2017): Terminska i opcijska tržišta ugljikovodika. Rudarsko-geološkonaftni zbornik (The Mining-Geology-Petroleum Engineering Bulletin), 32, 4, 45-54. https://doi.org/10.17794/ rgn.2017.4.5

Ordoudis, C., Pinson P. and Morales J. M. (2019): An integrated market for electricity and natural gas systems with stochastic power producers. European Journal of Operational Research, 272(2), 652-654. https://doi.org/10.1016/j. ejor.2018.06.036

Wu, W., Ma, X., Zeng, B., Lv, W., Wang, Y. and Li, W. (2020): A novel Grey Bernoulli model for short-term natural gas consumption forecasting. Applied Mathematical Modelling, 84, 393-404. https://doi.org/10.1016/j.apm.2020.04.006

\section{Papers written in non-English language:}

Jovanovac, J., Predavec, V., Vizec, Z., Štedul, M. (2019): Pružanje informacija korisnicima transportnog sustava $u$ skladu sa Uredbom EU 312/2014 - izazovi i rješenja (Providing information to transmission system users in accordance with EU Regulation 312/2014 - challanges and solutions), 34. međunarodni znanstveno-stručni susret stručnjaka za plin, 8. - 10. svibnja, 2019., Opatija (in Croatian - without English abstract)

Kevo, D. (2020): Tržište energije uravnoteženja transportnog sustava plina u Republici Hrvatskoj (Balancing market of Croatian gas transmission system) Diplomski rad. Zagreb: Sveučilište u Zagrebu, Rudarsko-geološko-naftni fakultet, 14.02.2020. (in Croatian - with English abstract)

\section{Internet sources:}

URL1: British Petroleum (BP) (2018): Statistical Review of World Energy. URL: https://www.bp.com/content/dam/ $\mathrm{bp} /$ business-sites/en/global/corporate/pdfs/energy-economics/statistical-review/bp-stats-review-2018-full-report.pdf (accessed 2.7.2019.)

URL2: European Commission (2014): Commission Regulation (EU) No 312/2014 of 26 March 2014 establishing a Network Code on Gas Balancing of Transmission Networks, OJ L 91, 27.3.2014, p. 15-35. URL: https://eur-lex. europa.eu/legal-content/EN/TXT/HTML/?uri=CELEX:32 014R0312\&from $=\mathrm{EN}$ (accessed 20.5.2019.)

URL3: Hrvatska energetska regulatorna agencija (HERA) (2016): Odluka o naknadi za organiziranje tržišta plina, NN 23/2016, 16.3.2016. URL: https://narodne-novine. nn.hr/clanci/sluzbeni/2016_03_23_652.html (accessed 27.6.2019.)

URL4: Hrvatska energetska regulatorna agencija (HERA) (2018): Mrežna pravila plinskog distribucijskog sustava, Narodne novine, br. 50/18, 88/19, 36/20. URL: https:// narodne-novine.nn.hr/clanci/sluzbeni/2018_06_50_1004. html (accessed 22.5.2019.)

URL5: Hrvatski operator tržišta energije (HROTE) (2018): Pravila o organizaciji tržišta plina, Narodne novine, br. 50/18. URL: https://narodne-novine.nn.hr/clanci/sluzbeni/ 2018_06_50_1007.html (accessed 20.5.2019.)

URL6: Hrvatski operator tržišta energije (HROTE) (2019a): Virtualna točka trgovanja. URL: https://www.hrote.hr/virtualna-tocka-trgovanja (accessed 29.5.2019.)

URL7: Hrvatski operator tržišta energije (HROTE) (2019b): Energija uravnoteženja. URL: https://www.hrote.hr/energija-uravnotezenja-109 (accessed 29.5.2019.)

URL8: Hrvatski operator tržišta energije (HROTE), (2019c): Obračuni: Neutralnost. URL: https://www.hrote.hr/obracuni (accessed 29.5.2019.)

URL9: Plinacro d.o.o. (2018): Mrežna pravila transportnog sustava, Narodne novine, br. 50/18, 31/19, 89/19, 36/20. URL: https://narodne-novine.nn.hr/clanci/sluzbeni/2018_ 06_50_1009.html (accessed 22.5.2019.)

URL10: Plinacro d.o.o. (2019a): Pravila postupanja operatora transportnog sustava. URL: http://www.plinacro.hr/default.aspx?id=815 (accessed 2.7.2019.) 
URL11: Plinacro d.o.o. (2019b): Transparentnost-Uredba 715/2009. URL: http://www.plinacro.hr/default.aspx?id= 109 (accessed 4.6.2019.)

URL12: Plinacro d.o.o. (2019c): Virtualna točka trgovanja. URL: http://www.plinacro.hr/default.aspx?id=104 (accessed 29.5.2019.)

URL13: Plinacro d.o.o. (2019d): Procjena ukupnog odstupanja na kraju plinskog dana. URL: http://www.plinacro.hr/ default.aspx?id=785 (accessed 2.7.2019.)
URL14: Sabor Republike Hrvatske (Croatian Parlament) (2018): Zakon o tržištu plina, Narodne novine 18/2018, 23/20. URL: https://narodne-novine.nn.hr/clanci/sluzbeni/ 2018_02_18_372.html (accessed: 20.5.2019.)

\section{SAŽETAK}

\section{Analiza tržišta energije uravnoteženja plinskoga transportnog sustava u Republici Hrvatskoj}

Mrežna pravila o uravnoteženju plina transportnih mreža stimuliraju razvoj veleprodajnoga tržišta plina poticanjem voditelja bilančnih skupina na korištenje standardiziranih mehanizama uravnoteženja. Za održavanje ravnoteže vlastite bilančne skupine mogu se koristiti renominacije korištenja ulaznih i izlaznih kapaciteta, trgovanje na virtualnoj točki trgovanja ili trgovanje na trgovinskoj platformi. U slučaju neravnoteže sustava Plinacro kao operator transportnoga sustava plina u RH aktivira energiju uravnoteženja kako bi vratio sustav u prihvatljive granice odstupanja. Na temelju analize slučaja odabrane bilančne skupine analiziran je godišnji primjer izračuna u kojemu, sukladno Pravilima o organizaciji tržišta plina, operator tržišta plina za svaki mjesec provodi obračun naknade za dnevno odstupanje, trgovanja provedenih na trgovinskoj platformi radi poduzetih radnji uravnoteženja, naknade za neutralnost te odstupanja od nominacije. U radu je prikazano kako voditelj bilančne skupine može imati pravo na naknadu ili biti dužan platiti naknadu temeljem mjesečnoga obračuna operatora tržišta plina, HROTE-a, a ovisno o iznosu pojedine naknade. HROTE priprema novi model za raspodjelu količina plina koji će utjecati na rad sudionika na tržištu plina, posebice bilančnih skupina. Na temelju analize zaključuje se kako bi preciznija procjena potrošnje za bilančnu skupinu predstavljala optimizaciju troškova i razvoj transparentnoga tržišta plina.

\section{Ključne riječi:}

pozitivna energija uravnoteženja, negativna energija uravnoteženja, bilančna skupina, trgovinska platforma, virtualna točka trgovanja

\section{Author's contribution}

Dominik Kevo (mag. ing. petrol, junior gas trade expert), as the main author of this paper, analysed the methodology of balancing the gas system, participated in writing all versions of the paper, collected data for examples of positive and negative balancing energy and visualized several figures and tables. Ivan Smajla (mag. ing. petrol, teaching assistant, PhD student) participated in the conceptualization of the paper (graphic and tabular presentation of data), visualized several figures, participated in the writing of certain chapters and edited the paper. Daria Karasalihović Sedlar (PhD full professor) devised the concept of the paper, participated in the writing of chapters, researched multiple sources of literature and made the most important conclusions of the paper. Filip Božić (mag. ing. petrol, senior gas trade expert) analysed the daily balancing of the market, collected data for the same, visualized several figures and participated in the writing of certain chapters. 